\title{
Experiences with the privatization of home care: evidence from Denmark
}

\section{Barbara Fersch}

Department of Economics, Politics and Public Administration

Aalborg University

Email: fersch@epa.aau.dk

\section{Per H. Jensen}

Centre for Comparative Welfare Studies

Aalborg University

Email: perh@epa.aau.dk

\begin{abstract}
Processes of privatization in home care for the elderly in Denmark have primarily taken the form of outsourcing public-care provisions. The content and quality of services have in principle remained the same, but the providers of services have changed. The welfare state has continued to bear the major responsibility for the provision of elderly care, while outsourcing has allowed clients to choose between public and private providers of care. The major aim of outsourcing has been to empower the frail elderly by providing them with exit-opportunities through a construction of this group as consumers of welfare-state provisions. The central government in Denmark has produced the public-service reform, but the municipalities bear the administrative and financial responsibility for care for the elderly. Further, national policymakers have decided that local authorities (municipalities) must provide to individuals requiring care the opportunities to choose. With this background in mind, this article analyses how national, top-down ideas and the 'politics of choice' have created tensions locally in the form of municipal resistance and blockages. The article draws on case studies in two Danish municipalities, whereby central politicians and administrative leaders have been interviewed. We have identified four areas of tensions: 1) those between liberal and libertarian ideas and values versus local political orientations and practices; 2) new tensions and lines of demarcation among political actors, where old political conflicts no longer holds; 3) tensions between promises and actual delivery, due to insufficient control of private contractors; and 4) those between market principles and the professional ethics of care providers.
\end{abstract}

Keywords: elderly care, home care, free choice, marketization, privatization, political conflicts, Denmark 


\section{Introduction}

The organization of elderly care has changed dramatically in most Western countries in recent decades. Where care was previously provided within households and kin networks, it is now a public activity subsidized by the welfare state. This development has led to the marketization of intimacy and the commodification of care (Ungerson, 2000, p. 69). The trend towards the marketization of intimacy has assumed different forms in different countries or contexts. A distinction can be drawn between paid informal (black market work), semi-formal (cash for care) and formal (care provided by paid employees in the social services or a voluntary agency) forms of care (Ungerson, 1997; Geissler \& Pfau-Effinger, 2005; Jensen \& Møberg, 2011). In the Danish Social Democratic Welfare State, formal forms of care have become predominant (Andersen \& Jensen, 2011, pp. 280ff). Care has become a universal citizen's right, with the municipalities being responsible for operating the elderly-care sector, and services offered include housing and care facilities for the elderly, as well as personal and practical assistance in the form of home care. As formal forms of care are predominant in Denmark, care givers provide care to persons outside of their family, and care giving has become a profession-like occupation. Care givers are unionized, public salaried employees, and their wages and work conditions are regulated by the social partners, that is, unions and employers' associations. In effect, care givers are paid wages equivalent to those that are paid to persons with similar qualifications, hours of work are regulated, and social rights, such as sick leave, are derived from employment in care. In 2005, roughly 100000 persons - about 3.7 per cent of the total labour force (calculated as full-time employees) - were employed in the public elderly-care sector (cf. Jensen \& Rathlev, 2009).

With home care, municipalities could freely choose until the early 2000s whether they wanted to make use of private (for-profit) contractors or whether all staff in the home-care sector should be municipally employed. However, municipalities were reluctant to make use of their outsourcing opportunities. By March 2002, only about 2.5 per cent of home care for those over 67 years was provided by private contractors (Strukturkommissionen, 2004). By January 1, 2003, however, a Liberal-led, right-of-centre government introduced public care service reform according to which the recipients of home care would be free to choose from different providers (public or private for-profit) of home care, meaning that municipalities became obliged to contract out the provision of home care if individual citizens so desired.

As in other European countries (e.g., Knijn, 2000; Pavolini \& Ranci, 2004; Whitfield, 2006), the elderly-care reform in Denmark was inspired by liberal and libertarian values, epitomized as the 'freedom to choose', which was believed to empower seniors by providing them with opportunities to choose. This constructed them as the consumers of welfare services (cf. Morris, 1997) while at the same time reinforcing the superiority of the market as a decisionmaking mechanism. Clarke (2004) and Clarke et al. (2007) have strongly argued that 'free choice' is a proxy for deeper processes of privatization and that the introduction of 'free choice' is a vanguard of 'direct' forms of privatization, that is, the transfer of services, organizations, and resources to the private (for-profit) sector. However, the organizational design of the 'free choice' of elderly care in Denmark has thus far (only) taken the form of outsourcing as well as the creation of a new provider market by supporting the formation of for-profit service providers. 
Free choice as a key organizing principle in elderly care was legislated at the national level. Neither the users nor the providers of care from below demanded the new policies. Rather, national politicians with neo-liberal convictions defined a new orientation with regard to the future of public services in the face of relatively autonomous municipalities, which are responsible for defining and financing policy outputs. ${ }^{1}$ Increased choice, or exit-opportunities, in the area of elderly care was thus imposed on autonomous local politicians and administration from above. Such top-down imposed policies might have contributed to new tensions and contradictions, not least because the local level is able to resist or block 'politics of choice'. As will be shown, municipalities are in practice able to facilitate or hinder the entrance of private for-profit providers into the care market.

With this background in mind, this study has sought to shed light on the following questions. How do local municipal actors in politics and administration deal with the introduction of choice and market mechanisms in elderly care? How do they react to national politics of choice, and how do they obstruct or ease the process for private providers of entering the care market? How do they see and perceive the consequences of the introduction of choice for the quality of care work, on the one hand, and the working conditions among care givers (i.e., the staff), on the other? To do so, this article draws upon qualitative interviews held with local actors in the administration of two different municipalities, and aims to reach a conclusion on how privatization creates tensions between pervasive ideas and local orientation and practices. The two municipalities represent two different approaches and orientations regarding the 'politics of choice'. Whereas one municipality was 'enthusiastic' about outsourcing and competition, the other was 'sceptical'. In the conclusion, we reflect upon the tensions, contradictions, and local reactions that have emerged from the top-down reform of public home-care services for seniors.

\section{The local system of elderly care in Denmark}

It is important to understand the context in which the 'politics of choice' were introduced in Denmark. There are 98 municipalities in Denmark, and these municipalities play a central role in the provision of care to senior citizens. The relevant legislation, the Social Services Act, stipulates that the municipalities bear the responsibility for the care for senior citizens. Elderly care is a citizen's right, and the municipalities must offer personal assistance and care together with help or support relating to necessary practical work in the home. Like other Scandinavian countries, the municipalities thus bear the main responsibility for running residential homes and nursing homes, and for providing staff and practical care in the form of home help (Szebehely, 2005; Trydegård \& Thorslund, 2010). Still, contrasts in elderly care exist between the Scandinavian countries. While Denmark's provision of elderly care complies with the image of the Scandinavian social-service model, Sweden's deviates significantly from this image (Rauch, 2007).

The municipalities have considerable autonomy and room to manoeuvre when it comes to the actual extent and substance of the care, however, as well as the situations in which one is entitled to receive care (cf. Jensen et al., 2004).

\footnotetext{
${ }^{1}$ Factors such as ageing populations (e.g., Ungerson, 2005), the overload of the welfare-state apparatus (e.g., Offe, 1982), and differentiation or individualization (e.g. Rostgaard, 2006) played a role to advancing the care reform, but these factors do not necessarily call for a liberal-inspired reforms.
} 
This means that the municipal council has extensive authority to define the level of municipal services (quality, coverage, etc.) for seniors. Still, the municipalities are obliged to make their political priorities and level of services visible to the municipal residents. The municipalities have been required to establish quality standards for municipal services since 1999. These standards must indicate the level of service that the municipal council has set for the municipality, just as the municipalities are required to install particular control mechanisms aimed at ensuring the fulfilment of the quality standards.

The connection between policy and financial responsibilities is very close in the area of elderly care. The municipality defines the content of elderly-care services, and the municipalities finance elderly care entirely (municipal spending in Denmark accounts for approximately 55 per cent of the total public expenditures). Danish municipalities have the authority to tax income, which, in combination with user fees, is the most significant source of municipal revenue. Taxes and user fees accounted for 56 per cent of the combined revenues for municipalities in 2002. Other sources of revenue include operating and installation revenues, refunds, borrowing, and compensatory payments (from the state). Compensatory payments aim to level out the conditions between rich and poor municipalities with respect to spending needs, tax bases, and other factors (Strukturkommissionen, 2004).

Overall, there has been a strong tendency in Denmark towards the formalization of care for seniors and such care becoming a public responsibility. By the end of the 1980s, however, the public sector and formal care for seniors had been restructured. Denmark has been marked by a trend towards 'de-institutionalization'. Home care and residential homes replaced senior housing, which led to an increase in home care (i.e., personal assistance, care, and assistance with practical tasks in the home). The most common type of home care is cleaning. Home care aims to keep seniors with reduced functional capacity (physical or mental) in their own home as long as possible.

This shift towards de-institutionalization has been accompanied by a trend towards flexible and private (free choice) care for seniors (Rostgaard, 2006). With regard to home care, municipalities could freely choose until January 1 , 2003 whether they wanted to opt for a private contractor or whether all of the staff in the 'home-care sector' should be municipally employed. Since January 1,2003 , however, the care receiver has been free to choose from among different home care providers, that is, public or for-profit private providers.

Not just anyone can establish a private company and provide home care. The municipality must first recognize these companies, and this recognition is based on the quality and price requirements outlined by the municipality. The municipality must also control the compliance of private contractors with quality standards. The municipality - not the care receiver - must pay directly to the private contractor for services delivered, and the municipality is responsible for all of the paperwork associated with the delivery of for-profit private home care. In other words, the scheme is not based on cash-for-care principles. Private contractors cannot, therefore, compete on the price for care, but private contractors have some advantages in attracting costumer's vis-à-vis the public care provision. Private contractors are allowed to offer additional services such as gardening or dog-walking to the care receiver, and the care receivers themselves must pay for these additional services. Public providers of care are only allowed to offer personal assistance and help for domestic tasks. All the same, the overall responsibility of providing care remains with the municipality. If a private contractor were to choose to stop 
delivering care to a specific individual, the municipality is obliged to assume the provision of care. ${ }^{2}$

\section{Cases and methods}

The data used in this article originates from case studies of Danish municipal governance structure in the area of elderly care, and two cases have been selected and compared. The two cases have been selected on the basis of 'most similar' design criteria (e.g., Lijphart, 1975). The two municipalities resemble each other with regard to numerous structural characteristics, including the tax base, debt, degree of urbanization, and the percentage of elderly, frail individuals who have chosen a private home care provider (cf. Indenrigs- og Sundhedsministeriet, 2011). The two municipalities differ from each other, however, regarding population size and how much money the municipalities spend per senior per year on elderly care. Furthermore, the two municipalities differ markedly when it comes to local policies, organizational structures, and practices concerning the introduction of privatization and choice. These marked differences are mirrored in different cultural orientations towards the 'politics of choice'. In Municipality A, the central actors appeared to be quite 'enthusiastic' about the introduction of economic principles, whereas in Municipality B they seemed quite 'sceptical'.

Both municipalities have a lengthy historical tradition of electing a Social Democratic (local) government. It is peculiar, then, that in the last election in 2010 , the sceptical municipality, B, produced a Liberal majority, whereas the enthusiastic municipality, A, continued under a Social Democratic banner. Municipality $A$ is not only characterized by political stability, but it is also marked by administrative stability and continuity. The seniority among the interviewed administrative staff is much greater in Municipality A (7-11 years) as compared with the seniority in Municipality B (1-4 years). The same pattern of continuity and discontinuity can even be found with regard to the person chairing the municipal seniors committee, which is responsible for all questions relating to the elderly before the municipal council. In Municipality $A$, the chair celebrated his 40-year anniversary in this position, while the chair in Municipality B was a newly elected municipal council member.

The different orientations in the two municipalities have had an impact on the magnitude of private providers. The number of private providers is much larger in Municipality A, where individuals requiring care can choose between 18 providers (13 private and five public providers), whereas only five providers (four private and one public) can be found in Municipality B (Servicestyrelsen, 2011).

The 'core' of the empirical material consists of qualitative interviews with the central actors involved in the formulation and implementation of local care policies. In 2010 we interviewed the most important political and administrative actors in relation to local elderly care. In each municipality, we have interviewed one elected politician, that is, the chair of the municipal senior committee. Moreover, we have interviewed persons in key positions within the local administrations, including: (1) the chief executive in the social administration (including elderly care) and overall head of all of the administrative staff interviewed; (2) the head of the care-assessment unit. The care-assessment unit serves a dual role of assessing care needs and grants

${ }^{2}$ According to the legislation, private contractors can not refuse their services to citizens, and they cannot terminate a contract (§ 15). In practice, however, they can. 
care while and at the same time of controlling the quality of services delivered by private and public home-care providers; (3) the head of the municipal elderly-care unit, who is the overall head of all municipal providers of elderly care; and (4) the municipal elderly-care unit is subdivided into sections (district organizations) and we have interviewed the head of a district organization. Additional information has been taken from official municipal documents, such as the official quality standard in the municipality.

Not all interviewees spoke unequivocally. The interviewed actors expressed quite different (or even opposing) approaches regarding the introduction of economic and market principles into the organization of elderly care. Our criterion for distinguishing between 'enthusiastic' and 'sceptical' municipalities is, however, that most interviewed actors in Municipality A were in favour of the introduction of market mechanisms, whereas the vast majority of those interviewed in Municipality B appeared to be rather sceptical towards the phenomenon.

\title{
Local policies, municipal service organizations, and forms of competition
}

All Danish municipalities have an elderly care unit responsible for the overall provision of elderly care within the municipality. The care unit is sub-divided into districts covering different geographical areas within the municipality. The districts are responsible for the delivery of public home care to the client or user. At the time of the interviews, there were five districts and 13 private providers of care in Municipality A, and four districts and four private providers in Municipality B. In the latter, the older person could choose between the municipal provider (home help will be delivered from the district in which the senior lives) or from one of four private providers. Quite unusually, it is not only possible in Municipality A to choose between public or private provisions, but also between the five municipal service units.

\begin{abstract}
We have chosen an organizational structure in which the municipal providers compete with each other, because the user can also choose between the municipal providers. This is a little bit atypical, I think. Normally, one can choose between the municipal provider and private providers. But here we've chosen to go one step further... (The chief executive in the social administration in Municipality $A)^{3}$
\end{abstract}

The reason for this 'dual' competition, that is, internal as well as external, is that the chief executive in the social administration in Municipality $A$ is able to influence the competition. The chief executive believed that competition would improve the quality of municipal services:

Well, I am committed to competition. And I am committed to the idea that we in the public sector should be exposed to competition all of the time in order to be forced to be cutting-edge. Without any question. (The chief executive in social administration, Municipality A)

Another interviewee from the administration, however, the head of the care assessment unit in Municipality A, was more critical about the chosen 'onestep-further' competitive structure. She states:

Instead of installing free choice between private and public, we've installed free choice between five municipal providers. And then you don't have the time for the private providers... Well, we absolutely don't

\footnotetext{
${ }^{3}$ All interview quotations have been translated from Danish to English by the authors.
} 
have the time to have meetings with them, to inform them, to check on them, and to keep them at bay and to say to them, 'Now you have to document things', and things like that... (Head of care assessment unit, Municipality A)

This interviewee indicated that 'dual' competition may become an obstacle for efficiency and cause negligence in the control of private providers. This was not a critique of private provisions; rather, it referred mainly to the enhanced competitive structures in Municipality A. Her experience and interpretation of the situation are based on her position as the head of the care-assessment unit in charge of controlling both the private and public providers of care.

Conversely, Municipality B has employed a less competitive organizational structure, and clients or users have fewer opportunities to choose compared to Municipality A. They can choose between three private providers and the public offerings. If the client or user chooses the public option, services will be delivered from the district unit covering the receiver's place of residence. In Municipality $B$, the atmosphere that stifles competition is even supported by practices of blockage:

We don't have any private providers for meals on wheels. The political system is against that... I almost said... they are of course not against it, but they make demands that don't make it easy for the private providers to access the market. ... The word is - at least in our department - that it's because they demand skilled kitchen staff - even for the delivery of food. Everywhere else, it's just a driver who can read an address and run the meal upstairs. (Head of care assessment unit, Municipality B)

As can be seen, the special demands set by Municipality B restrict the access to the care market for private contractors. These restrictions are not informal practices, since they are clearly spelled out in the quality standards for municipal services. Under the item 'delivery' in the quality standards regarding 'meals on wheels' in Municipality B, it is stated:

The meal ought to be delivered by skilled staff so that the citizen receives adequate instructions concerning the meal and answers to any questions. (Quality standards Municipality $\mathrm{B} ;{ }^{4}$ cf. National Board of Social Services, 2011)

The quality standards for the delivery of 'meals on wheels' in Municipality A are quite different. Here, the following requirements must be fulfilled:

The drivers must understand and speak Danish. The drivers must be familiar with the pensioners' possible special problems, and they must meet them with understanding and flexibility. (Quality standards Municipality A, Source: National Board of Social Services 2011)

The drivers in Municipality B must clearly be skilled staff, whereas this is not the case in Municipality A. This possibly helps to explain why there is no private provider of meals on wheels in Municipality $B$, whereas there is one in Municipality A.

The interviewed head of a district organization in Municipality B seems to describe these tendencies in more general terms:

But I think it [the choice between private and public providers] did not receive as much importance as it possibly could have gotten. And I'm not

\footnotetext{
${ }^{4}$ The authors have translated the quotes from the quality standards of municipalities $A$ and B from Danish to English.
} 
surprised, because there are no equal market conditions. ... This might be a little hypocritical. But it probably depends on what kinds of politicians you have in the municipality. There are some other municipalities ... which have privatized their senior centres and that kind of thing... So it's possible one way or another (Head of district organization, Municipality B).

This quotation demonstrates how municipalities within the same legislative framework can create different environmental conditions from which private providers can emerge. Municipalities may support the formation of private providers by creating 'equal market conditions' for public and private providers, or they might resist or block the formation of private providers in the face of the ideas and intentions of national policymakers.

The comparison between municipalities $A$ and $B$ outlines two distinct patterns in the organizational structure and practices. In Municipality A, most of the interviewed actors were positive or enthusiastic about competition and 'politics of choice'. Municipality A had even taken competition a step further than was envisaged, by introducing competition between the municipal district units in addition to the competition between public and private providers. This structure, however, has been criticized from within for being inefficient and undermining the control mechanisms. In Municipality $\mathrm{B}$, on the other hand, the introduction of economic principles appears to have been delayed and impeded by various forms of resistance. Local policymakers can restrict the market for private providers, as seen in the case of the obstructive quality standards set on the meals-on-wheels service.

\section{Patterns of interpretation}

It is often argued that competition enhances the quality of services, and the chief executives in the social administration in both municipalities appear to support such basic ideas. Even the chief executive in the social administration in sceptical Municipality B made the following statement:

\footnotetext{
I think it's really fine that the user can choose between public and private home care services. ... And our quality awareness and costconsciousness and so on clearly got sharpened by the fact that we have competition. So it's really fine. I would be sad if they were not there anymore. (The chief executive in the social administration, Municipality B)
}

However, competition can also have a negative effect on the quality of care. As described above, the head of the care assessment unit in Municipality $A$ believed that complex and competitive structures drain the resources for controlling private providers, which in turn threaten the quality of care:

They [the private providers] do allow themselves ... not to document anything about the individual citizen, even though they have to. Well, because they just have to work profitably and to earn money with that, they don't get it done, even though it's actually a requirement for them... And until now, there was no case in which they have been reprimanded for not doing so. (Head of care assessment unit, Municipality A)

The interviewee's colleague in Municipality B, a clear 'sceptic', thinks that the private competitors actually do provide a lower quality of care:

The private firm is usually able to have more unskilled staff than the municipal home care. What they have to provide is the same - the same services. And well, to be completely honest ... I think it's a somewhat 
poor alternative to municipal home care. And so the question is where to give the money that one uses for these services; if one thinks that it is really fantastic to give it to private providers or if one rather lets it circulate in the public system... (Head of care assessment unit, Municipality B)

This interviewee drew a connection between the educational backgrounds of the care givers and the quality of the care: a lower proportion of skilled staff is expected to mean lower quality care.

Some anticipated that the introduction of market mechanisms would have an effect on the staff's and care givers' professional self-understanding and work ethics. One head of district in Municipality A emphasized the positive consequences of market mechanisms and cost-benefit thinking:

Well, in any case, the fact that the private providers came in did mean that we had to look at our own tasks with different eyes. And that we also had to look at what we're doing today. And all of a sudden, we had to put time and a price on everything we do. That was a good experience for a lot of the employees - that they all of a sudden found out, well it isn't something we just do... ... So for many of our employees, it meant that they felt that they were growing a little professionally by focusing on what they're doing. And all of a sudden what they were doing became very visible. And suddenly, what they did had a value (Head of district organization, Municipality A)

In line with this argument is the notion that the introduction of economic thinking casts light on the economic value of caring and fosters the recognition of care work and care workers. Standardization in the sense of 'putting' a time and price on every task may actually support the processes of professionalization. Hanne Marlene Dahl (2009), who has analysed how care workers handle the implementation of New Public Management (NPM) within home care in two Danish municipalities, has argued that NPM reforms may lead to increased recognition of care work. NPM can also lead to increased misrecognition, however, depending on how NPM reforms are translated into work practices. 'The different translations of NPM ... matter a great deal for their impact on recognition and misrecognition' (Dahl, 2009, p. 649). Similarly, we find different interpretations in municipalities $A$ and $B$ regarding how the fortification of economic principles affects the ethics and quality of care work: For me, welfare services depend on relations. In reality, I don't like the
word 'services' - for me it's not the right word when it comes to relations.
Because services are something more tangible, concrete that you give to
a customer. The term 'service' also comes from a different world. So all
of this terminology we have about it ... also 'level of service', for
example. Service is something we provide to a citizen. One tends to
forget that, in reality, one is cooperating and establishing a relationship
[with the senior]. And here, I do see a risk when it comes to the
perspective that the citizen is a customer ... it becomes a business
transaction instead of saying that it is actually the establishment of a
relationship. And it is really very much about finding out what kind of
needs the individual actually has. (Head of elderly care unit, Municipality
B)

Here, the interviewee points to care as a reciprocal relationship based on responsibility and relatedness, a topic which has also a focus in the academic discussion of care (see also Daly \& Lewis, 2000). Later on, when asked about her individual definition of good elderly care, the same interviewee again emphasizes 'basic values' such as 'responsibility' and 'respect'. In her view, 
the specific character of care work makes any 'privatization' efforts difficult. This leads her to being one of the 'sceptics' in Municipality B:

\begin{abstract}
One must be very aware that it [elderly care] is not just some... some... some thing, or something you can just do to someone ... And here I do see some risks. But it's not like I'm completely against it - you can't say that. I just think that you shouldn't go into it in a starry-eyed manner. I think you should be very aware about who does what in such situations. (Head of elderly care unit, Municipality B)
\end{abstract}

Another aspect that is criticized by nearly all of the interviewed actors although, as we shall see later on, with different motives and diverse conclusions - is the fact that no real privatization took place, in other words, that the privatization in the context of Danish elderly care was actually outsourcing. Home care was not understood as a 'real' market. The socialadministration chief executive in Municipality A (a competition enthusiast) was really annoyed about the fact that there were no genuine market conditions in the field of home care:

\begin{abstract}
I disagree strongly with how it is today - that there's no competition over price. I just don't get it ... Because without competition over price, what's left from the private sector? At the end of the day, isn't it what the private sector is grounded in? That there should be competition over price? But I would also like to have marketization in the sense ... that the users should pay much more themselves. So that seniors could buy from the private providers what they miss from the level of service that we provide - as some kind of base ... I think that would be really fine. But here again, I think something is wrong today. (Head of social administration, Municipality A)
\end{abstract}

Earlier on, the same interviewee made it clear that she saw competition as a means of enhancing quality and of enforcing development in municipal elderly care. In this context, we can see how she criticizes the Danish 'imperfect' form of marketization as a hindrance to the unfolding of what would have otherwise been proclaimed to be the great effects of market competition. She criticized two main aspects. First, that there was no competition over price, and secondly, that seniors did not pay at least part of the services themselves, because that is how a market usually works. Earlier in the interview, she already made it clear that she only sees the provision of personal care as a public responsibility and that she would embrace making practical help like cleaning as services which seniors must pay out of their own pockets.

A common point made by many of the interviewees was the claim that private and municipal providers do not compete on an equal footing:

\footnotetext{
The municipalities are challenged by the fact that we must always be ready to overtake the citizen again and that we have to provide 24-hour coverage. And that's costly. So as a firm you can opt out of these tasks but you can't do it as a municipality. That challenges the municipalities in this competitive world through unequal conditions. (Head of elderly care unit, Municipality A)
}

This interviewee emphasizes that the private providers have some advantages within the market, since the municipality must act as a 'last resort' and is responsible for assuming the costly and non-profitable tasks. One of the district heads in Municipality B underlined an additional aspect of the unequal market participation:

What I think isn't okay is that one ... isn't equal. For example, the private providers can provide extra cleaning for extra payment. We can't. ... We 
don't have equal conditions ... There are things we are not allowed to do. And we have to take over. If a citizen is tired of the private firm, we have to take over. Whereas the private providers can ... say 'no thanks', and they can pick and choose. And then it's the municipality that takes over. (Head of district organization, Municipality B)

Hence, the last two actors criticized the policy of privatization in Denmark for favouring private providers and leaving the more costly, less attractive tasks to the municipalities. Whereas the 'enthusiastic' head of social administration in Municipality A criticized the 'imperfect' privatization for hindering the 'blessings' of market principles and competition, the other two interviewees criticized how the home care market is constructed, which benefits private providers vis-à-vis municipalities.

As can be seen, different interviewees and actors assigned privatization to different meanings and consequences. Some of the interviewees saw a positive impact on the quality of care from competition and the market mechanism, while others saw the introduction of a market and private competitors as a threat. When it comes to the impact on care work and care workers (the staff), we again see opposed interpretations of the consequences of privatization. One interviewee believed that market mechanisms strengthen the recognition of care work; another saw it as a threat to care-work ethics. There were also different interpretations regarding the actual functioning of the market mechanisms. Some argued that the 'market' is constructed in such a manner (i.e., outsourcing) that the rewards from privatization are suppressed; others believed that private providers are privileged.

\section{Conclusion}

Since the early 2000s, the Danish right-of-centre government has supported the establishment of private home-care providers in order to help to shift the provision of care and resources from the public to the private sector. This endeavour has been imposed on autonomous local municipalities from above, even though municipalities already had the opportunity to contract out service provisions prior to the service reform in 2003 if they wanted to do so. As of 2003 , however, the free choice of local political communities has only been tolerated as long as it is exercised in the right direction.

Nevertheless, the abstract values of free choice have never become a reality. The municipalities still define which services clients are entitled to receive. It is not like a supermarket, where clients can choose between different products. Rather, clients will be offered a product or service defined by the public authorities. Accordingly, the 'politics of choice' only allow clients to choose whether the municipality or a for-profit private contractor delivers a pre-defined commodity (or service).

A genuine 'politics of choice' in Denmark is also undermined because of the neutralization of market or price mechanisms. Because there is no real competition over price, the only incentives for care receivers to choose a private instead of a public provider are, first, that clients feel more comfortable with a private rather than a public provider of care, and, secondly, that private providers, contrary to public providers, are allowed to offer additional services. Even though a relatively small proportion of total care is provided by private contractors, privatization policies in elderly home care in Denmark have created several layers of tensions. 
In Denmark, municipalities bear the responsibility for providing care for senior citizens, and municipalities control how quality standards in public and private (for-profit) care are defined locally. These standards can be defined in ways that tend to exclude private contractors. In one of the municipalities examined in this article, we have found that this municipality demands that the provision of meals on wheels can only be delivered by skilled kitchen staff, which makes it difficult (i.e., expensive) for private contractors to access the care market. This creates tension between the overall idea of choice as a political value versus local political orientations and practices.

Different municipalities and different actors within municipalities are oriented differently towards the 'politics of choice'. On the basis of our case study, we draw a distinction between 'enthusiastic' and 'sceptical' municipalities and actors, which indicates that the same phenomenon is interpreted quite differently by different actors. This causes local political struggles and conflicts. However, the demarcation between the 'enthusiastic' and the 'sceptical' does not follow conventional political thinking. It was a Liberal-led government that introduced 'politics of choice', but our case studies show how the Social Democratic municipality is 'enthusiastic', whereas the Liberal municipality is 'sceptical'. The 'politics of choice' thus gives rise to new kinds of tensions and lines of division among political actors.

In addition, we have found a tension between what is promised and what is actually delivered. The municipality defines the quality standards, and these quality standards may deviate from what is actually delivered by private contractors, who tend to deprive older people of what they are actually entitled to get. Such tensions may occur owing to the insufficient control of private contractors. The municipalities are responsible for controlling the quality of services delivered by private providers, but the control can be inadequate. In our case study, we have found examples showing a lack of resources to control private providers. A similar tension between promises and delivery arises because private contractors are inclined to use unskilled staff to maximize profits.

Finally, tensions between professional ethics and market principles may arise, since cost-benefit thinking tends to pose a threat to the ethics of the profession-like occupation of care. This tension, however, is not clear-cut. At least administrative leaders in the two municipalities report that outsourcing and the introduction of market mechanisms have also led to the increased recognition of care workers because the introduction of private contractors has led to a self-reflexive process regarding the distinctive qualities of care work.

\section{References}

Andersen, J. G., \& Jensen, P. H. (2011). Ældreudfordringen: tilbagetrækning, pensioner og ældrepleje [The challenges of ageing: withdrawal, pensions, and elderly care]. In I. H. Møller \& J.E. Larsen (Eds), Socialpolitik, (pp. 269-285). København: Hans Reitzels.

Clarke, J. (2004). Dissolving the public realm? The logics and limits of neo-liberalism. Journal of Social Policy, 33(1), 27-48.

Clarke, J., Newman, J., \& Westmarland, L. (2007). The antagonisms of choice: New Labour and the reform of public services. Social Policy \& Society, 7(2), 245253. 
Dahl, H. M. (2009). New Public Management, care and struggles about recognition. Critical Social Policy, 29(4), 634-654.

Daly, M., \& Lewis, J. (2000). The concept of social care and the analysis of contemporary welfare states. British Journal of Sociology, 51(2), 281-298.

Geissler, B., \& Pfau-Effinger, B. (2005). Change of European care arrangements. In $B$. Pfau- Effinger \& B. Geissler (Eds), Care arrangements in Europe: variations and change (pp. 3-17). Bristol: Policy Press.

Indenrigs- og Sundhedsministeriet (2011). De Kommunale Nøgletal [The key numbers for municipalities]. Retrieved from (18 March 2011) http://www.noegletal.dk/

Jensen, P. H., Larsen, C. A., \& Stoltenborg, H. O. (2004). ÆEldre og ældrepolitik [The elderly and policy on the elderly]. In Larsen, J. E., \& Møller, I. H. (Eds.) Socialpolitik [Social policy] (pp. 237-248). København: Hans Reitzels.

Jensen, P. H., \& Rathlev, J. (2009). Formal and Informal Work in the Danish Social Democratic Welfare State. In B. Pfau-Effinger, L. Flaquer, \& P.H. Jensen (Eds), Formal and informal work: the hidden work regime in Europe (pp. 3961). New York \& London: Routledge.

Jensen, P. H. \& Møberg, R. J. (2011). Tensions related to the transition of elderly care from an unpaid to a paid activity. In B. Pfau-Effinger \& T. Rostgaard (Eds), Care between work and welfare in European societies (forthcoming). London, Chicago: Palgrave.

Knijn, T. (2000). Marketization and the struggling logics of (home) care in the Netherlands. In M.H. Meyer (Ed), Care work: gender labor and the welfare state, (pp. 232-248). London: Routledge.

Lijphart, A. (1975). The comparable-cases strategy in comparative research. Comparative Political Studies, 8(2), 158-177.

Morris, J. (1997). Care or empowerment? A disability rights perspective. Social Policy \& Administration, 31(1), 54-60.

Offe, C. (1982). Some contradictions of the modern welfare state. Critical Social Policy, 2(5), 7-16.

Pavolini, E., \& Ranci, C. (2004). Restructuring the welfare state: reforms in long-term care in Western European countries. Journal of European Social Policy, 18(3), 246-259.

Rauch, D. (2007). Is there really a Scandinavian social service model? A comparison of childcare and elderlycare in six European countries. Acta Sociologica, 50(3), 249-269

Rostgaard, T. (2006). Constructing the care consumer: free choice of home care for the elderly in Denmark. European Societies, 8(3), 443-463.

Servicestyrelsen (2011): Fritvalgsdatabasen [Optional database]. Retrieved from (18 March 2011) http://www.fritvalgsdatabasen.dk/kommunereport.

Strukturkommissionen (2004). Strukturkommissionens betænkning - Bind III [Report from The Commission on Political and Administrative Structures, vol. III]. København

Szebehely, M. (Ed.), (2005). Äldreomsorgsforskning i Norden [Research on elderly care in the Nordic countries]. Köpenhamn: TemaNord, 2005:508

Trydegård, G.-B., \& Thorslund, M. (2010). One uniform welfare state or a multitude of welfare municipalities? The evolution of local variation in Swedish eldercare. Social Policy and Administration, 44(4), 495-511.

Ungerson, C. (1997). Give them the money: is cash a route to empowerment? Social Policy \& Administration, 31(1), 45-53.

Ungerson, C. (2000). Cash in Care. In M.H. Meyer (Ed.), Care work: gender, class and the welfare state. London, UK: Routledge. 
Ungerson, C. (2005). Gender, labour markets and care work in five European funding regimes. In B. Pfau-Effinger \& B. Geissler, (Eds), Care and Social Integration in European Societies (pp. 49-72). Bristol: Policy Press.

Whitfield, D. (2006). A typology of privatisation and marketisation. European Services Strategy Unit, ESSU Research Report, no. 1. 